\title{
Effects of Processing Method on the Nutrients' Composition of Maize/Soya Complementary Food
}

\author{
${ }^{1}$ Ademulegun Temitope Isaac, ${ }^{2}$ Koleosho A.T. \\ ${ }^{1,2}$ Nutrition and Dietetics Department Rufus Giwa Polytechnic P. M. B 1019, Owo, Ondo State, Nigeria.
}

\begin{abstract}
To improve the physical characteristics, nutritional composition and reduce the anti-nutritional content of complementary food, different processing methods had been used. This study was carried out with a view of comparing the effect of three processing methods on the nutrient composition of maize/soy complementary food. Flour of fermented, sprouted and toasted maize and toasted soybean was separately produced. The three maize flours were separately blended with the toasted soybean in the ratio 70:30 to produce three blends of maize/soya complementary foods labeled A (toasted soybean + toasted maize), B (toasted soybean + fermented maize and $C$ (toasted soybean + sprouted maize). The resulting blends were subjected to proximate, vitamin $C$ and mineral analysis. The energy, protein, vitamin $C$ and some mineral contents of the blends were compared with that of commercial maize/soy complementary food (Nutriend). The result showed that the three processing methods gave complementary food that contained protein $(19.64 \%$ to $21.60 \%)$ and energy $(430.15 \mathrm{kcal} / \mathrm{g}$ to $451.27 \mathrm{kcal} / \mathrm{g})$ that were higher than that of the commercial complementary food $17 \%$ protein and $400 \mathrm{kcal} / \mathrm{g}$. The blends also contained significantly higher $(P<0.05)$ levels of phosphorus and vitamin $C$ than nutriend. However nutriend contains significantly higher $(P<0.05)$ level of calcium than the processed blends. The three processing methods gave weaning food with adequate amount of protein, energy, phosphorus and vitamin C. However, the cheapest and least time consuming process is toasting. Further biological study on the utilization of the nutrient needs to be carried out.
\end{abstract}

Keywords: Maize/Soya, Complementary Food, Processing, Nutrients.

\section{Introduction}

Weaning is the gradual replacement of breast milk by a good mixed diet. It is usually carried out when the baby has attained the weight of $5.9 \mathrm{~kg}$ and age of $5-6$ months $^{(10)}$. After six months, an infant continues to receive breast milk but also needs increasing amount of additional foods known as complementary or weaning foods. Weaning foods are needed to fill the gap between the total nutritional needs of the child and the amount provided by the breast milk and also bridge the change in milk diet to adult food ${ }^{(19)}$.

A variety of complementary foods are commercially available with high nutritive value, which are directly used for instant preparation of gruels. However, in many developing countries, these products are beyond the economic means of most families. So mothers use traditional gruels - water suspensions of maize or sorghum, as complementary foods for infants. These gruels usually have low energy density and poor protein, vitamin and mineral contents ${ }^{(9,13)}$. Thus, protein-energy malnutrition is a common problem among infant and children in the poor socio-economic groups of developing countries ${ }^{(8)}$.

Several strategies may be used to improve the nutritive value of complementary foods. The traditional complementary food could be improved by combining locally available food that complement each other in such a way that the new pattern of amino acids created by this combination is similar to that recommended for infants ${ }^{(18)}$. Cereals are deficient in lysine but have sufficient sulphur-containing amino acids (methionine) that are limiting in legumes. Therefore, the combination of cereals and legume has been found to produce amino acid patterns that adequately promote growth ${ }^{(7,2,6)}$.

The processing technique used for this purpose has been largely fermentation, sprouting/germination and less often toasting ${ }^{(5,14)}$. Fermentation enhances the nutritive value of food by increasing thiamine, nicotinic acid, riboflavin and perhaps, protein content as a result of microbial activity ${ }^{(15)}$. Lopez et $a l^{(11)}$ noted that minerals were made more available and phosphorus was released from phytate during fermentation of corn. Fermentation and germination can reduce the high bulk of traditional complementary food by reducing the viscosity of the cereal gruel or porridge ${ }^{(17)}$. Toasting reduces the viscosity of gruel, inactivates lipase and increases the shelf life of weaning food ${ }^{(5)}$. The objective of this research is to determine the effect of three types of processing methods (fermentation, sprouting and toasting) on the nutrient composition of maize/soy complementary food with a view to recommending the best for household production of weaning foods. 


\section{Materials and Methods}

Source of raw materials: Yellow maize and soybeans were purchased from Ikoko Market, Owo, Ondo State, Nigeria.

Processing of materials: The two ingredients for the formulation were processed into flour of fermented maize (FMF), sprouted maize (SMF) toasted maize (TMF) and toasted soybeans (TSF).

Processing method for fermented maize flour: The maize grains were sorted by removing stones and other physical contaminants. This was followed by cleaning the sorted maize with water. It was then steeped in water for 72-hr for fermentation to occur. The fermented maize was wet milled using attrition mill and then sieved. This was allowed to settle overnight, the maize slurry was put in a clean muslin cloth and squeezed to remove the water, this was oven dried $\left(60^{\circ} \mathrm{C}\right.$, for $\left.12 \mathrm{hrs}\right)$ milled and packaged.

Processing method for sprouted maize flour: The maize grains were cleaned by hand sorting and floated to remove broken grains and extraneous materials. The grains were soaked in tap water for $9 \mathrm{hrs}$ at ambient temperature. The hydrated grain were drained and spread thinly on wet jute bags and covered with another layer of jute bag. The grains were germinated for $72 \mathrm{hrs}$ with watering every six hours. Ungerminated grains were discarded while the germinated with the sprouts were oven dried $\left(50^{\circ} \mathrm{C}\right.$ for $\left.12 \mathrm{hrs}\right)$ and milled to flour, sieved and packaged.

Processing method for toasted maize flour: Maize grains were sorted to remove all extraneous materials. The clean maize was toasted for 15 minutes. The roasted maize was milled, using attrition mill, to fine particle, sieved and packaged.

Processing method for toasted soybean flour: The soybeans were thoroughly sorted to remove all extraneous materials. The clean beans were toasted for about 15 minutes and then dehulled, followed by winnowing, milling and sieving. The flour was then packaged.

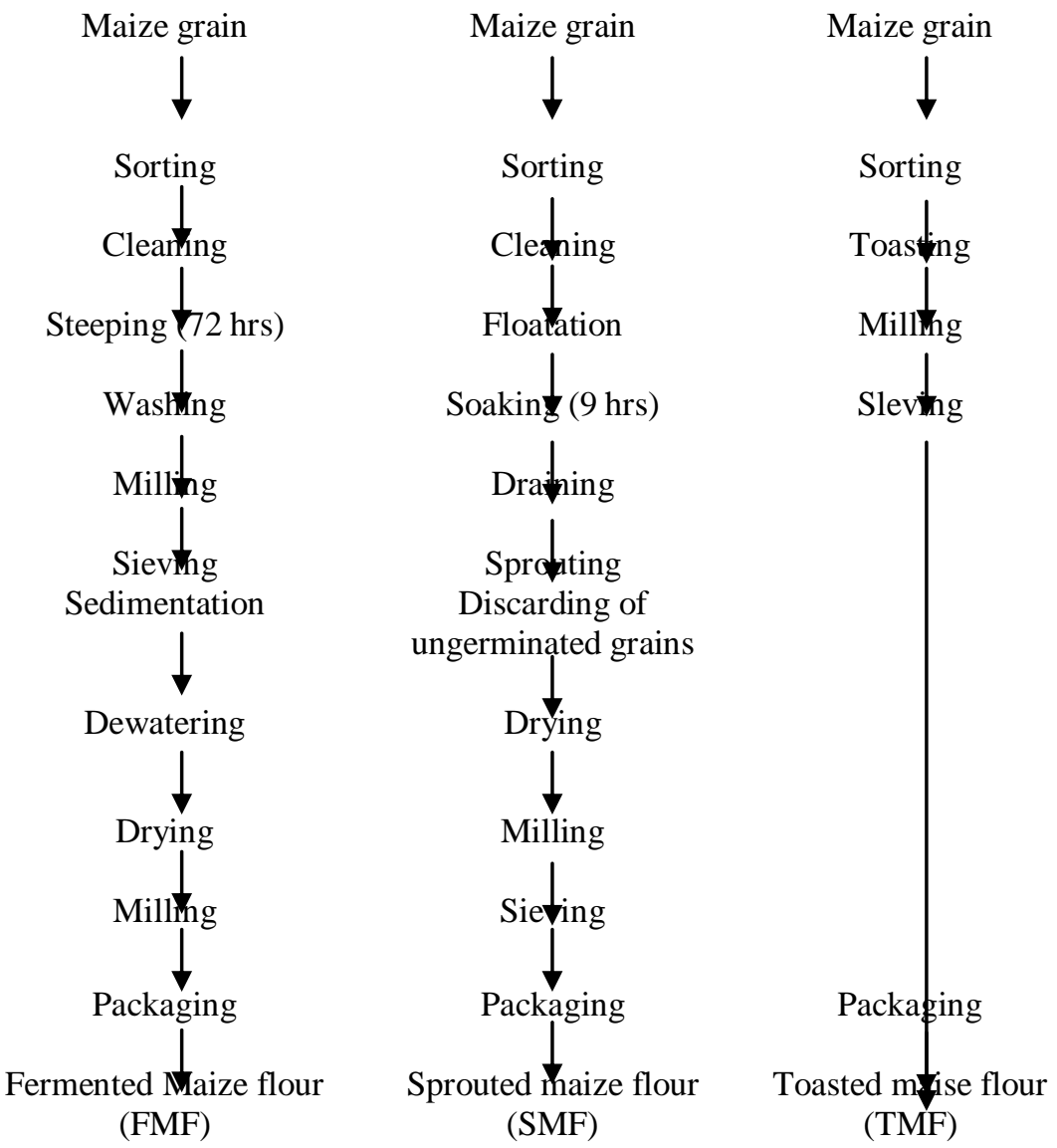

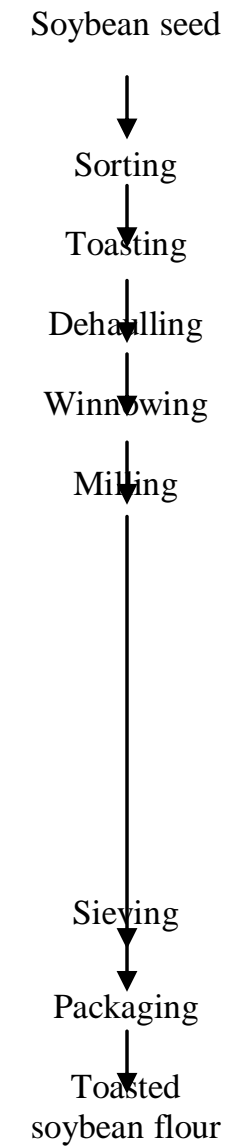

(TSF)

Fig. 1: Flow chart for the processing of maize-soya weaning food ingredients into flour

Formulation of maize-soya weaning food: The flours were used to formulate the maize-soya weaning food in the following ratio:

$\mathrm{A}=70 \%$ fermented maize flour (FMF): $30 \%$ toasted soybean four (TSF)

$\mathrm{B}=70 \%$ sprouted maize flour: $30 \%$ toasted soybean flour (TSF)

$\mathrm{C}=70 \%$ toasted maize flour: $30 \%$ toasted soybean flour (TS) 
Chemically Analysis: The samples of the three blends were separately analysed for proximate composition using the official standard methods ${ }^{(1)}$. The carbohydrate was obtained by difference. The gross energy values were estimated by multiplying the crude protein, fat and carbohydrate by their at water values of 4,9 and $4 \mathrm{kcal} / \mathrm{g}$ respectively. Calcium was determined using atomic absorption spectrometer (210 bulks scientific) while phosphorus was determined by calorimetric method using Vanodo molybdate method. Vitamin C was determined using Pearson method ${ }^{(4)}$.

Analysis of Results: The results obtained were subjected to analysis of variance (ANOVA) and the Duncan multiple range test used to separate means $(\mathrm{P}<0.05)$.

\section{Results}

The proximate composition of the three differently processed maize/Soya weaning food is shown in Table 1.

Table 1: Proximate Composition of the three maize/Soya complementary food

\begin{tabular}{|c|c|c|c|}
\hline PARAMETERS & A & B & $\mathrm{C}$ \\
\hline & $\overline{\mathrm{TS}}+\mathrm{TM}$ & $\overline{\mathrm{TS}}+\mathrm{FM}$ & $\overline{\mathrm{TS}}+\mathrm{SM}$ \\
\hline Moisture \% & $2.68 \pm 0.02^{\mathrm{a}}$ & $3.99 \pm 0.08^{\mathrm{a}}$ & $3.21 \pm 0.08^{a}$ \\
\hline Protein $\%$ & $19.64 \pm 0.02^{\mathrm{a}}$ & $19.70 \pm 0.02^{\mathrm{a}}$ & $21.60 \pm 0.02^{\mathrm{a}}$ \\
\hline Ash \% & $2.04 \pm 0.02^{\mathrm{a}}$ & $2.37 \pm 0.02^{\mathrm{a}}$ & $1.62 \pm 0.02^{\mathrm{a}}$ \\
\hline Fat $\%$ & $1.63 \pm 0.05^{\mathrm{b}}$ & $14.97 \pm 0.02^{\mathrm{a}}$ & $16.55 \pm 0.03^{\mathrm{a}}$ \\
\hline Fiber $\%$ & $2.28 \pm 0.02^{\mathrm{a}}$ & $2.42 \pm 0.02^{\mathrm{a}}$ & $3.03 \pm 0.03^{\mathrm{a}}$ \\
\hline Carbohydrate $\%$ & $61.73 \pm 0.09^{\mathrm{a}}$ & $56.55 \pm 0.09^{b}$ & $53.95 \pm 0.02^{c}$ \\
\hline Energy $(\mathrm{kcal} / 100 \mathrm{~g})$ & $430.15^{\mathrm{c}}$ & $439.73^{b}$ & $451.27^{\mathrm{a}}$ \\
\hline
\end{tabular}

The moisture content of the complementary food samples ranged from $2.68 \%$ to $3.99 \%$ for the toasted soybean/toasted maize and toasted soybean/fermented maize respectively, while that of toasted soybean/sprouted maize as $3.21 \%$. Though the TS + FM weaning food had the highest value (3.99\%) but this was not significantly different $(\mathrm{P}<0.05)$ from the values for the other two samples.

The protein content of the sample varies from $19.64 \%$ (for TS + TM) to $21.60 \%$ for (TS + SM), while that of TS + FM was $19.70 \%$. The values were not significantly different $(\mathrm{P}>0.05)$. The ash content of the samples were $1.62 \%, 2.04 \%$ and $2.37 \%$ for $\mathrm{C}$, A and B respectively.

The maize/soybean complementary food fat content ranged from $1.63 \%$ to $16.55 \%$ for TS + TM and TS+SM respectively. The fat content of TS + SM was significantly higher $(\mathrm{P}<0.05)$ than that of TS + TM but not significantly different from that of TS + FM. The fiber content of the samples varied from $2.28 \%$ to $3.03 \%$. The carbohydrate content of the three differently processed maize/soybean complementary food ranged between $53.95 \%$ (for $\mathrm{TS}+\mathrm{SM}$ ) and $61.73 \%$ (for $\mathrm{TS}+\mathrm{TM})$. There was significant difference $(\mathrm{P}<0.05)$ in the carbohydrate content of the weaning food.

The energy content of the maize/soybean weaning food was significantly different $(\mathrm{P}<0.05)$ and ranged from $430.15 \mathrm{kcal} / 100 \mathrm{~g}$ to $451.2 \mathrm{kcal} / 100 \mathrm{~g}$.

The vitamin $\mathrm{C}$, phosphorus and calcium contents of the three differently processed maize/soybean weaning food are shown in table 2.

Table 2: Vitamin C, phosphorus and calcium composition of three maize/soybean complementary food

\begin{tabular}{llll}
\hline PARAMETERS & \multicolumn{3}{c}{ SAMPLES } \\
\hline & A & B & C \\
Vitamin C (mg/100g) & $71.98 \pm 1.48^{\mathrm{c}}$ & $89.66 \pm 1.74^{\mathrm{a}}$ & $86.35 \pm 0.74^{\mathrm{a}}$ \\
Phosphorus (mg/100g) & $553 \pm 6.44^{\mathrm{c}}$ & $586 \pm 2.00^{\mathrm{a}}$ & $570 \pm 5.00^{\mathrm{b}}$ \\
Calcium $(\mathrm{mg} / 100 \mathrm{~g})$ & $220 \pm 2.55^{\mathrm{b}}$ & $225 \pm 2.55^{\mathrm{a}}$ & $218 \pm 0.00^{\mathrm{b}}$ \\
\hline
\end{tabular}

${ }^{a, b, c}=$ values with the same superscripts along the row are not significantly different $(P<0.05)$

The vitamin $\mathrm{C}$ content of the complementary foods was significantly different from one another $(\mathrm{P}<0.05)$ with TS + FM having the highest value of $89.66 \mathrm{mg} / 100 \mathrm{~g}$ and TS + TM having the least value of $71.98 \mathrm{mg} / 100 \mathrm{~g}$.

The phosphorus content varies from $553 \mathrm{mg} / 100 \mathrm{~g}$ to $586 / 100 \mathrm{~g}$. The samples' phosphorus content was significantly different from one another. 
The calcium content of TS + FM $(225 \mathrm{mg} / 100 \mathrm{~g})$ was significantly higher $(\mathrm{P}<0.05)$ than that of the other two samples.

Table 3 shows the comparative composition of some nutrient in the differently processed maize/Soybean weaning food and a commercial maize/soya weaning food (nutriend).

Table 3: Comparative nutrient composition of differently processed and commercial Maize/Soya complementary food

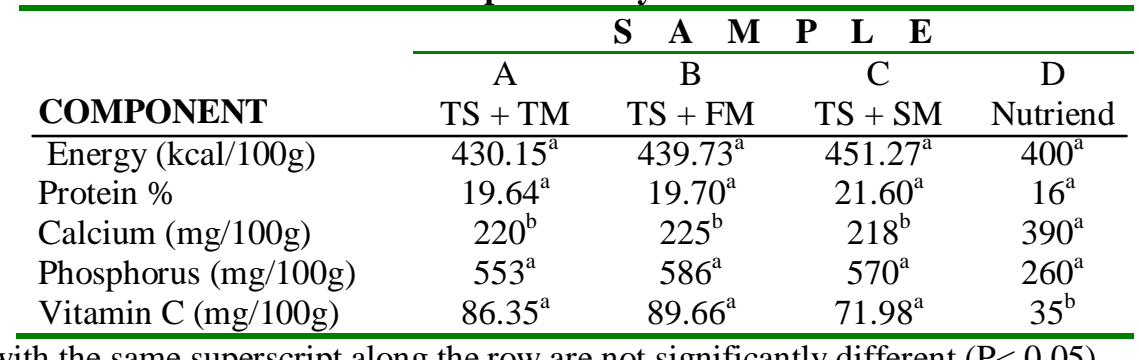

${ }^{\text {a, b. }}=$ Values with the same superscript along the row are not significantly different $(\mathrm{P}<0.05)$

There was no significantly difference $(\mathrm{P}<0.05)$ between the commercially produced and the locally processed maize/soy weaning food in terms of energy and protein content, though the commercial weaning food has a lower content. The commercially produced maize/soya weaning food (nutriend) has a significantly lower value of phosphorus and Vitamin $\mathrm{C}$ but has a significantly higher content of calcium than the locally produced weaning food.

\section{Discussion}

The inclusion of soybean increased the protein level appreciably. The highest $(21.60 \%)$ protein content observed for sample containing sprouted maize might be due to the production of excess amino acids during sprouting and their accumulation in the free amino acid pool and for further protein synthesis ${ }^{(3,16)}$. The higher value (19.70) of protein recorded for the fermented maize could be as a result of microbial activities which can cause the insitu synthesis of protein and the fact that micro organisms normally use carbohydrates in preference to protein and lipid ${ }^{(12)}$. The least value $(19.64 \%)$ of protein recorded for sample containing toasted maize could be attributed to protein denaturation when heated.

The highest carbohydrate content of sample containing toasted maize might be due to the high level of starch granules in toasted sample while the low values for samples containing fermented and sprouted maize could be due to the utilization by fermenting micro organism for growth and metabolic activities of the organisms and germination.

Total ash determines the level of mineral element present in the samples. Toasting caused an increase in ash content due to volatilization of organic content.

The microbial release of bound minerals will lead to increase in ash content while mineral utilization for the metabolic process of sprouting will cause a reduction in ash content.

Weakening of fibre during toasting and its enzymatic breakdown during fermentation caused a reduction of crude fibre content while the utilization of carbohydrates in the seed during sprouting leaves a high fibrous seed.

Energy value of each sample is a function of protein, fat and carbohydrate content. Both fermentation and sprouting had been reported to have increasing effect on Vitamin $C^{(3)}$ while toasting destroys Vitamin $C$.

\section{Conclusion and Recommendation}

The three processing methods gave weaning food with higher content of protein, energy, phosphorus and vitamin C than typical Maize/Soya commercial weaning food. But the cheapest and least time consuming process is toasting.

However, to have a balanced calcium and protein content of the household produced Maize/Soya weaning food, egg shell and or fish bone could be incorporated while the ratio of maize to soybean should be increased. Since this study is limited to proximate composition, further biological study on the utilization of the nutrients should be carried out.

\section{References}

[1] AOAC (1990): Official Methods of Analysis (15th Edition). Association of official Analytical Chemist. Washington DC. USA.

[2] Akinrele, I. A. and Edward, C. (1971): An assessment of the nutritional value of maize soy mixture Soya Ogi as a complementary food in Nigeria Br. J. Nutrition 26: $172-185$.

[3] Alexia, J. M. (2007): Effect of sprouting on nutrient composition and some anti-nutritional factor of sorghum and soybean J. Food chemistry, Vol. 101: $1202-2111$. 
[4] David Pearson (1976): The Chemical Analysis of Food. National College of Food Technology, University of Reading, 7th Edition Church Hill Living Stone, Edinburgh and New York, Pg. $214-215$.

[5] Desikarcher, H. S. R. (1989): Cooking behaviour of Semoling from maize, sorghum, wheat and rice journal of food science and Technology 13: $34-36$.

[6] Ejigni, J.; Savoie, L. Marim J. and Desrosiers, T. (2007): Improvement of the nutritional quality of a traditional complementary porridge made of fermented yellow maize: Effect of maize - legume combinations and traditional processing methods. Food Nutri. Bull. 28(1): $23-34$.

[7] Fashakin, J. B. and Ogunsola, F. (1982): The utilization of local foods in formulation of weaning foods. Trop Paediatr Land 1982: 28: $93-6$.

[8] Gopalan ad Srikantia (1973): Nutrition and Disease. World Rev. Nutr. Diet 1973: 16: 97 - 140.

[9] Guiro, A. T.; Sail, M. G.; Kane, O.; Ndeaye, A. M.; Diarlia, D. (1987): Protein - calorie malnutrition in Senegalese children Effect of rehabilitation with Pearl Millet Complementary Food. Nutr. Reg. Int. 36: 107 - 109.

[10] Hegested, D. M. (1970): Theoretical estimates of protein requirement of children, protein in Nutrition Academic Press Inc.

[11] Lopez, Y.; Godon, D I.; Field, M L. (1983): Release of phosphorus from phytate by natural lactic acid fermentation. J. Food Sci. 48: $933-54$

[12] Mba-Anyadioha, A. E. (2008): Production and Evaluation of microbiologically safe complementary food based on fermented maize and soybean flours. Book of proceedings of the 39th Annual Conference and Scientific Meeting of the Nutrition Society of Nigeria, Pg. $26-31$.

[13] Njongmeta, LNA; Ejoh, RA.; Mbofung CM.; Verhoef, MJR. (2003): Weaning practices in the Adamawa Province of Cameroon Second International Conference on Food-Based Approaches for a Healthy Nutrition of West Africa, Ouagadougou, Burkina Faso, November, $23-28,2003$.

[14] Obizoba, I. C. and Ati, J. J. (1991): Effect of Soaking, sprouting, fermentation and cooking on nutrient composition and some anti-nutritional factors of sorghum seeds. J. Plant Food. Hum. Nutri. 41: $203-212$.

[15] Odunfa, S. A. (1985): African fermented foods: from art to science. In: Prague L. ed.. Development of Indigenous Fermented foods and food technology in Africa Proceedings of the IFS/UNV workshop held in Duala, Cameroom, October, 1985. Provisional Report No. 20; Stockholm: International Foundation for Science 1985: 17 - 33.

[16] Ogunka-Nnoka, C. U. and Mepba, N. D. (2007): Formulation of weaning foods with reduced bulk and high nutrient densities using soybean maize blends. Book of proceeding of the 38th Annual Conference of the Nutritional Society of Nigeria, Pg. $174-$ 177.

[17] Potter, N. N. and Hotchloss, H. J. (1995): Fermentation and other uses of microorganisms in food science. C. B.S. Publishers India, Pg. $254-268$.

[18] Uwaegbute, A. C. and Nnanyelugo, D. O. (1987): Usage patterns of cowpeas for infant feeing in Nigeria. In Kwik Whei L., Kiang, AI. (eds) Trends in Nutrition and Food Policy Proceeding of the 7th world congress of food science and Technology, 1987: $201-205$.

[19] World Health Organization (WHO) (2000): Complementary feeding, Family Food for breast fed children Department of Nutrition for Health and Development. France. 